\title{
地下水の地球化学調査に関わるデータ品質評価手法の提案*
}

\author{
水野 崇**·Richard METCALFE $* * *$. 岩月輝希 $* *$ 彌榮英樹 $* * * *$
}

\section{Proposal for quality assessment method of groundwater chemistry for hydrochemical investigation *}

\author{
Takashi MIZUNO **, Richard METCALFE***, \\ Teruki IWATSUKI ** and Hideki MIE ****
}

\begin{abstract}
Hydrochemical studies are generally conducted based on chemical data of groundwater samples. Various methodologies exist for obtaining samples and for assessing the quality of the collected sample. This study is aimed at establishing a methodology for quality assessment of chemical data obtained from groundwater samples using a method known as Evidence Support Logic. In this study, $\mathrm{pH}$ data of groundwater obtained from several boreholes were assessed using this method. The results showed that 23 out of 63 samples satisfied the applied quality criteria. When plotted, the data from the 23 samples show a constant value from top to bottom of investigation area when compared to a plot using data from all samples. These results indicate that the quality assessment method demonstrated by this study is applicable to groundwater studies and that by considering the sample quality it will be possible to develop a clearer interpretation of the deep underground geochemical environment.
\end{abstract}

Key Words: groundwater, hydrochemical study, quality assessment, Evidence Support Logic

\section{要旨}

本稿では、地下水データの品質を定量的に評価するための品質評価手法を確立することを目的と し、Evidence Support Logicに基づいた品質評価手法を提案した。当該手法を用いてボーリング孔か ら取得した $\mathrm{pH}$ データの品質評価を行った結果、全データを深度に対してプロットした場合には、 $\mathrm{pH}$ が 8〜11の広い範囲で分布したのに対し、一定の品質を満たしたデータでは 8〜9のより狭い範 囲に分布した。このことから、一定の品質を示したデータは、より正確に各深度の $\mathrm{pH}$ を表している と考えられ、本稿で提案した品質評価手法の有効性を示すことができた。

キーワード：地下水、地球化学研究、品質評価、Evidence Support Logic

本論文は2006年地球惑星科学関連学会合同大会（2006年 5 月）にて発表

** 日本原子力研究開発機構 地層処分研究開発部門 (

Japan Atomic Energy Agency, Geological Isolation Research and Development Directorate

*** 株式会社 クインテッサジャパン

Quintessa Japan Ltd.

**** 東電設計株式会社

Tokyo Electrical Power Services Co., Ltd. 


\section{1. はじめに}

近年、水資源開発や放射性廃棄物の地層処分研 究といった分野において、地下深部の地下水の地 球化学的研究が活発になりつつある（例えば、地下 水水質の基礎、2000; 小宮ほか、2003; Gascoyne, 2004）。これらの調査研究では、様々な調査研究 機関の研究者が井戸や湧水、ボーリング孔などか ら異なった方法で地下水試料を採取している。ま た、調査技術の進歩によって、過去に得られた データと新規に得られたデータにおける調査方法 の違いが、得られたデータの信頼度（品質）に直 接反映されることになる。その結果、個々の研究 者がこのような品質の異なるデー夕に基づいて解 析を行うこととなり、異なった解釈や結論に至る 危険性を生じさせることになる。これらの地下水 データを用いた研究の信頼性を高めるためには、 品質の違いを踏まえて解析を行う必要があり、取 得したデータの品質の違いが解析結果やその再現 性に与える影響を明確にするためには、追跡性を 確保することが不可欠である。各研究機関による 深部地下水の地球化学的研究は発展期にあり、こ の段階で様々な研究分野、機関の研究者が共有で きるデータの品質評価手法を構築しておくこと で、今後の調査研究の品質を共通化し、客観的に 深部地下水の地球化学特性を評価することが可能 になると考えられる。本稿では、地球化学デー夕 の品質評価手法を提案するとともに、これまでに 著者らが岐阜県東濃地域において様々な条件下で 取得した地球化学データを対象とした品質評価 と、その評価手法の実用性について述べる。

\section{2. 品質評価手法の提案}

様々な条件下で得られた地下水試料の品質を評 価し、比較した例として、スウェーデン核然料 . 廃棄物管理会社（SKB）がスウェーデンとフィン ランドの地下水を対象として行った品質評価例が ある（Laaksoharju et al., 1993）。SKBの例では、 水質の品質評価に係わる項目を定量的に判断でき る項目と専門家の判断に依存する項目に区分し、 それぞれの結果から地下水試料の品質を客観的に 表現する手法を用いている。ただし、この手法で
は地下水試料そのものの品質に焦点が当てられて おり、そこから得られた化学成分濃度等の各デー 夕についての品質を評価することはできない。実 際には、品質が低いと判断された地下水試料にお いても、そこから得られる幾つかのデー夕項目に おいては十分な品質を保っている可能性がある。 例えば、地下水採取時に嫌気条件を保てなかった 場合、酸化還元状態や $\mathrm{pH}$ は変化すると考えられ るが、主要化学成分の変化は少なく、有効なデー タとして使用することができる可能性が高い。し たがって、この方法では、特定のデータの品質を 否定することで、使用可能なデータが抹消される といった欠点もある。地下水試料そのものの品質 評価は重要であるが、その試料から得られた各 データがどのような品質にあるかを詳細に知るこ とができれば、研究テーマによっては、より多く のデータに基づいて高い精度で解析が可能になる と考えられる。本研究では、複数の根拠から設定 した仮説の真偽を定量的に評価する Evidence Support Logic (ESL) (Cui and Blockley, 1990; Foley et al., 1997; Hall et al., 1998; Blockley and Godfrey, 2000; Davis and Hall, 2003) に基づ いた品質評価手法の構築を試みた。

\section{1 ESL に基づく品質評価手法}

ESLの基本的な考え方は論理演算に類似してい るが、論理演算中で用いられる真偽の他に、「不

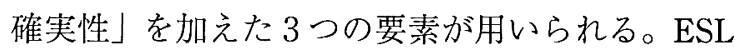
における不確実性とは、評価する命題が真とも偽 とも判断できない確率を示す。この不確実性を評 価結果に導入することが従来の評価手法とは大き く異なる点であり、ESLが有効と考えられる点で ある。実際の地下水データの品質を評価する際に は多くの考えられる指標（品質評価指標；掘削水 による污染率、脱ガスの有無、物理化学パラメー タの測定方法など）が存在する。しかし、一般的 な調査の過程において、それら全ての品質評価指 標に関する情報を取得するのは困難である。品質 評価を行う際に、品質評価のための情報が無い場 合、そのデータの品質は低いのではなく、不明と 判断されることが必要である。このような評価手 法を採用することにより、デー夕の品質に含まれ る不確実性の原因を抽出し、データの不確実性を 
低減させることができる可能性がある。そのため、 本研究では、従来行われているようなスコアリン グ方式や、画一的な基準を設ける品質評価手法で はなく、ESLを用いた品質評洒手法を試みた。

ESLによる品質評価を行うための最初のステッ プは、設定した仮説を証明するための根拠を抽出 し、関連項目によって分類し、階層構造（プロセ スモデル）を構築することである。プロセスモデ ルを構築する各プロセスは、それぞれの品質評価 指標およびそこから計算された結果としての真偽 および不確実性の割合を示す。各プロセスにおい ては、これら 3 つの要素の確率が示され、3つの 要素の和は 1 (=100\%) となり、真および偽は 0 から 1 の間の值を示す。不確実性は 1 から真と偽 の和を引いた数値となる。実際の各プロセスは Fig. 1の様に示され、この場合にはそのプロセス に設定した仮説において、真の確率が22\%、偽の 確率が34\%、不確実性が44\%であることを示して いる。Fig. 2にプロセスモデルの例を示す。Fig. 2 のプロセスモデルでは、仮説となるプロセス $\mathrm{P} の$ 真偽および不確実性を、プロセスI1とI2の異なる 2つの項目から計算している。このI1とI2は、そ れぞれに関連するE1およびE2、E3およびE4の それぞれ 2 つの根拠に基づき計算される。

Fig. 3の例では、2つの根拠から仮説を検討し た場合を示している。結果における真偽および不 確実性の確率は、品質評価指標 1 と品質評価指標 2 に示されたそれぞれの確率から計算されており、 下位のプロセスである品質評価指標 1 と品質評価 指標 2 では、定性的な情報や数值データ等により、 真偽および不確実性のそれぞれの值を決定する。

ESLではプロセス間の計算を行うために、プロ

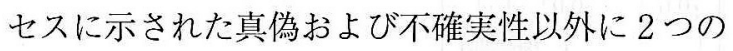
係数を用いている。それらは依存度と充足度と呼

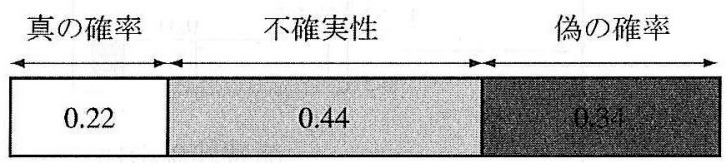

図1ESL 理論におけるプロセス中の真偽および不 確実性の確率の表示方法

Fig. 1 Format to indicate the ratio of "Evidence For", "Evidence Against" and "Uncertainty" in ESL logic.
ばれる（Fig. 3)。依存度は上位のプロセスが複数 の下位のプロセスにより算出される場合に、下位 のプロセスが示す真偽および不確実性が重複して いる割合を示しており、計算過程におけるダブル カウントの影響を排除する目的で用いられる。依 存度は 0 から 1 の間で表され、0の場合は独立、 1 の場合は完全に重複していることを示す。他 方、充足度は根拠となる下位のプロセスの重要度

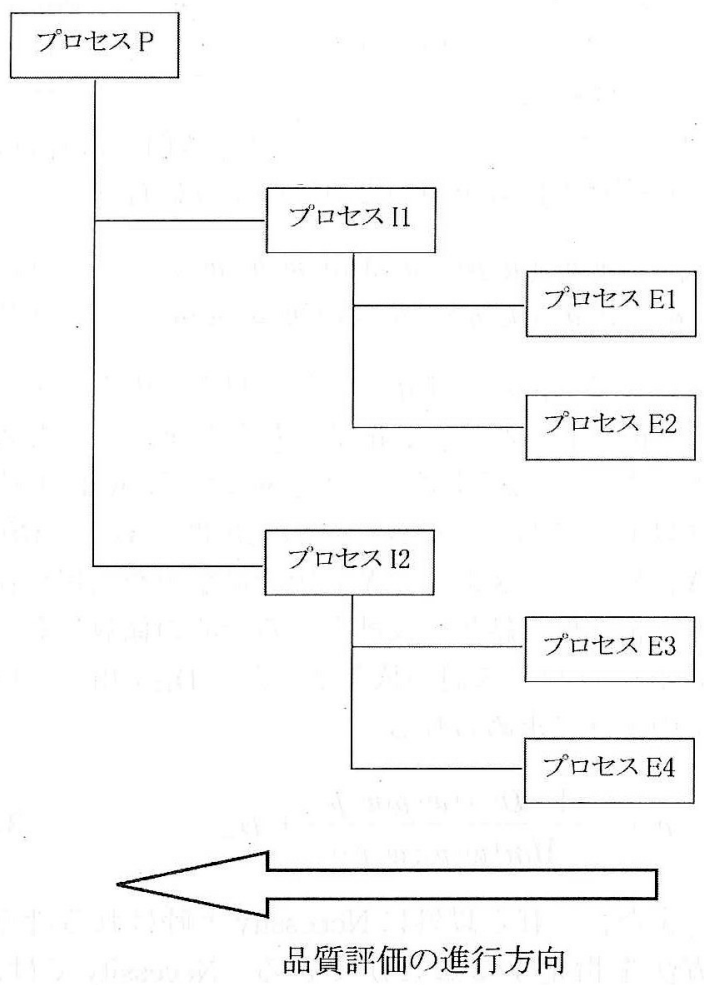

図 2 模式的なプロセスモデル

Fig. 2 Schematic diagram of process model

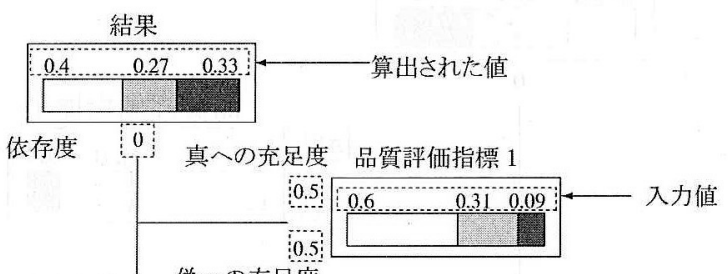

偽への充足度

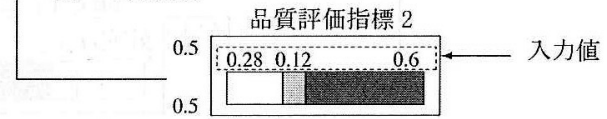

图 3 プロセス間の計算に用いられるパラメータ

Fig. 3 Parameters to calculate upper process 
を示しており、0から 1 の間もしくはALLおよ びANYで表される。ALLの場合には下位のプロ セスの中の最も小さい值が上位のプロセスの值と なり、反対にANYの場合には最も大きな值が採 用される (Fig. 4)。Fig. 4において、左側の場合 は真の充足度にALLが指定されており、值の小 さい品質評価指標 2 の值が結果に採用される。右 側の場合には、真の充足度に ANY が指定されて いることから、より大きな值である品質評価指標 1 の值が結果に採用される。これらの場合の偽の 值については、それぞれに設定された充足度 （0.5）に基づき計算する。プロセス間の計算は、 それぞれの係数を用いて以下のように行う。

$$
\begin{aligned}
& p_{0}=w_{1} p_{1}+w_{2} p_{2}-\rho_{12} \operatorname{Min}\left(w_{1} p_{1}, w_{2} p_{2}\right) \\
& q_{0}=w_{1} q_{1}+w_{2} q_{2}-\rho_{12} \operatorname{Min}\left(w_{1} q_{1}, w_{2} q_{2}\right)
\end{aligned}
$$

ここで、 $\mathrm{p}_{0}$ おび $\mathrm{q}_{0}$ は位プロセスの真および 偽、 $\mathrm{p}_{1} 、 \mathrm{q}_{1}$ およ゙ $\mathrm{p}_{2} 、 \mathrm{q}_{2}$ はそれぞれ下位プロセス の真および偽である。また、W1および $\mathrm{w}_{2}$ は下位 プロセスにおけるそれぞれの充足度である。Min $(X 、 Y)$ では、XおよびYの中で最小值が選択され る。依存度を結果へ反映させるための係数である $\rho_{12}$ は、プロセス間の依存度である $\mathrm{D}_{12}$ を用いて以 下のように求められる。

$$
\rho_{12}=\frac{\left(1-D_{12}\right)\left(w_{1} p_{1} w_{2} p_{2}\right)}{\operatorname{Min}\left(w_{1} p_{1}, w_{2} p_{2}\right)}+D_{12}
$$

また、これら以外に Necessity と呼ばれる計算 方法を指定することができる。Necessityでは、
真または偽のいずれかにしきい值を設定し、その 值を超えた下位のプロセスの值を強制的に上位へ 反映させる。具体的な計算方法を Fig. 5に示す。 Fig. 5では「偽>0.5」というしきい值を設定した 場合を示しており、品質評価指標 2 がそれに該当 するため、結果には品質評価指標 2 の值が採用さ れる。

\section{2 プロセスモデルの構築}

プロセスモデルは品質評価過程を明示するだけ でなく、品質に倸わる要因を網羅的に抽出するこ とで、品質が低い場合にはその原因を特定し、次 の調査に反映させるためにも重要である。本研究 では以下の手順でプロセスモデルを構築し、品質 評価を行った。

(1)元素の溶解、化学形態、吸着/収着に影響を与 える地球化学データの把握

(2)地下水に污染と化学的擾乱を起こす要因の抽出 (3)他の考慮すべき要因の抽出

(4)プロセスモデルの構築

(5)それぞれの要因における適・不適の基準の設定

(1)については、著者らが行っている高レベル放 射性廃棄物の地層処分に関する基盤研究におい て、放射性元素の挙動に影響を与える要因となる デー夕項目の品質を評価するための手法を開発す る必要があるため、 $\mathrm{pH}$ や酸化還元電位およびそ れらに影響を与える項目を品質評洒対象とした。 これらのデータ項目についてはそれぞれのプロセ スモデルを構築し、品質を評価する必要がある。
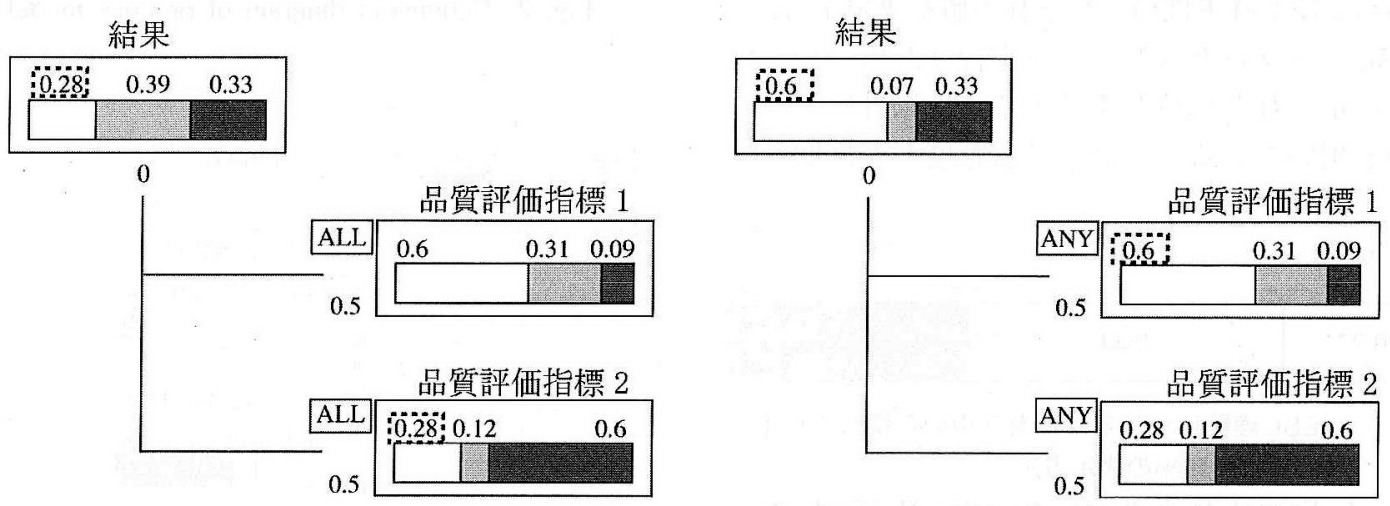

図 4 依存度に “ALL”もしくは “ANY”を用いた場合の計算方法

Fig. 4 Calculation method in the case of using "ALL" or "ANY" in dependency 
(2)では原位置の地下水に対して直接的に影響を与 える要因を抽出し、品質評価指標として設定し た。このような指標としては、ボーリング掘削時 に使用する掘削水の試料への混入による污染や、 試料採取区間以外からの地下水の流入による化学 特性の変化、試料採取時の脱ガスや酸化、採水過 程における掘削ズリや採水に用いられる機材との 反忘、微生物の影響が挙げられる。(3)では、(2)で 抽出した品質評価指標以外の、間接的ではあるが データに影響を与える、もしくは品質評価指標と なる可能性のある要因を抽出し、品質評価指標と して設定した。このような要因としては、目視に よる試料の確認結果や水理学的な要因などが挙げ られる。(4)では(2)および(3)で抽出した品質評価指 標を関連項目によって分類し、プロセスモデルを 構築した。この際に、抽出した品質評価指標を更 に細分化できる項目については細分化し、採水調 查の過程で取得した品質評価指標に係わるデータ と関連づけられるようにした。例えば、掘削水の 混入に関する項目では混入率を把握する指標を、 人為的に添加したトレーサーと、天然のトレー サーとなるトリチウムに細分し、それぞれのデー 夕から掘削水の混入を評価することが可能となる ようにした。(5)では、(4)で構築したプロセスモデ ルの最も下位のプロセスへの入力值を決定するた めの基準とそれに伴う入力值を設定した。それぞ れの基準に基づき各プロセスに入力する真および 偽の值は、 1 もしくは 0 とし（真が 1 の場合は全

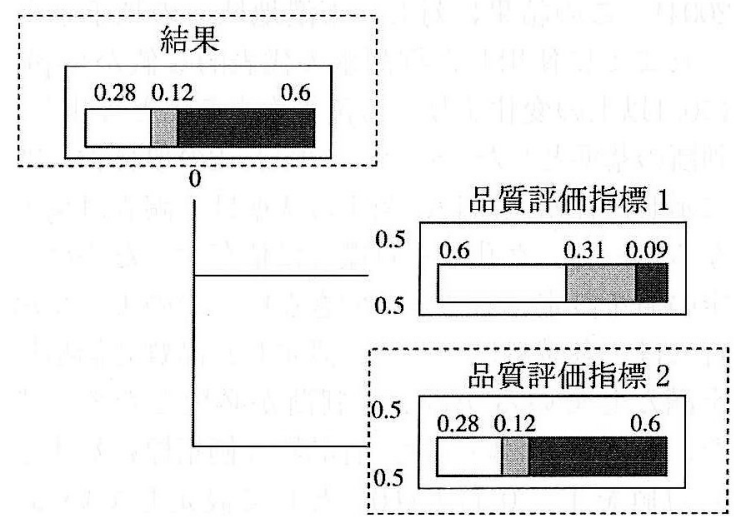

图 5 プロセス間の計算に “Necessary”を指定した 場合の計算方法

Fig. 5 Calculation method of "Necessary" case
く正しいことを意味する。この場合、偽および不 確実性の值は 0 となる。)、基準を細分化できる場 合については0．5を人力できるように設定した。 この基準の設定については後述する。

\section{3 計算に用いる係数の決定}

ESLに基づいて品質評価を行う場合には、プロ セス間の計算の際に用いられる係数である充足度 と依存度を決定する必要がある。これらの係数は 先に抽出した各品質評価指標の重要度を決定する こととなり、品質評価の上では重要である。ただ し、研究内容によって、重要となる品質評価指標 は異なると考えられる。例えば、地下水の $\mathrm{pH} の$ 品質を評価する際に、その反映先が採水調査手法 の開発に係わる研究であった場合、品質評価指標 の中でも調査手法に関わる品質評価項目である地 下水の污染率を把握する方法や採水方法、採水区 間の設定に関する項目が重要となる。一方、反映 先が酸化還元に関する研究であった場合、酸化還 元と関連する炭酸濃度やアルカリ度と $\mathrm{pH}$ の整合 性などが重要となると考えられる。また、あまり にも厳正に品質評価を行うことによって、全ての データの品質が一様に低くなるようでは品質を評 価したとは言えない。そのため、本研究では、プ ロセスモデルを構築した後に、各係数を蕨しい条 件として任意に設定し、品質が高いと想定できる 試料を参照して、全デー夕を合理的に評価できる ように係数を調整した。本研究でのプロセスモデ ルについて、依存度は全ての品質評価指標が独立 であると考え、全ての項目について0とした。ま た、充足度については、以下の 3 つの基本的な考 え方に則り決定した。

(1) $\mathrm{pH}$ の品質に対して重要度や与える影響が類似 していると考えられる場合には同じ充足度を用 いる。

(2)厳しい条件とするために、偽の充足度にはでき るだけ ANYを用いる。

(3) ALL を使用することで厳しい条件設定とする ことができるが、多用することにより不確実性 が増大し、品質のよいデータと悪いデータの区 別が困難になる可能性があるため、より上位の プロセスでのみ用いる。

(1)については、抽出した品質評価指標におい 
て、何を重要とするかという、品質評価者の主観 によるものであることは否めない。ここでは、筆 者らがこれまでの東濃地域を対象とした調查研究 で得られた経験や知見に基づき、掘削水による污 染が $\mathrm{pH}$ に与える影響として最も大きいと考え、 充足度はALLを除いた場合に最大の 1 とした。 (2)については、重要度が低い項目または通常の採 水調査で情報を取得しない項目については、ANY 以外の值を設定した。(3)については、最終的な計 算過程の他、重要と思われる測定機器の校正につ いてのみ適用した。

\section{3. 東濃地域の地下水を対象とした品質評価事例}

著者らは、岐阜県東濃地域において、深度 $1,000 \mathrm{~m}$ 付近までの地下水を研究対象として、地 球化学環境を調査・解析・評価する手法および技 術の開発を行っている。地下水試料は、主に地表 から掘削するボーリング孔の掘削途中もしくは掘 削後に行われる調査を通して採水しており、これ までに300点以上の試料を採取している（Furue et al., 2003)。

\section{1 地下水調査における品質管理}

採水調査時の品質管理については、古江ほか （2005）にまとめられており、品質の高い地下水 試料を採取するために重要な要素として、ボーリ ング孔の掘削に使用する掘削水による污染の評価 や被圧不活性状態での物理化学パラメータの測定 などが挙げられている。また、これらに対応する 手法として、掘削水による污染についてはトレー サーの添加に基づく混入率の把握、物理化学パラ メータの測定については、原位置での測定、もし くは地上にフローセルを設置しての嫌気環境下で の測定が挙げられている。これらの技術開発で は、採水装置の開発や採水方法の改善など、主に 調査現場において地下水試料の品質を低下させる ことなく採取するための手法開発に焦点が当てら れており、様々な条件下で得られた地下水デー夕 の品質評価手法は確立されていなかった。

実際にこれまでに行われてきた調査において は、調査の考え方や技術の進歩により、地下水に 対する主な污染源となるボーリング孔掘削時に用
いられる掘削水（掘削用原水ならびに掘削循環 水）の管理方法や、物理化学パラメータの測定条 件の違いなど、地下水の地球化学データの品質に 影響を与える要因も一様に管理されてきたわけで はなく、取得されたデー夕の品質にも差がある。

本研究では、調査時期や採水方法の異なる 9 本 のボーリング孔（DH-2、7、12号孔、MSB-2、4 号孔、KNA-6号孔、MIZ-1号孔、MIU-4号孔）か ら取得した 63 試料を対象として、試行的に品質評 価を行った。

\section{2 地下水の $\mathrm{pH}$ に関わる品質評価事例}

これまでに示した品質評価方法に沿って、地下 水の $\mathrm{pH}$ について品質評価を行った例を示す。63 試料について、採取方法と $\mathrm{pH}$ の測定方法につい ての概要を Table 1に示す。試料の採取と $\mathrm{pH}$ の測 定は、岩月ほか（1998）に示された方法で行った。 Fig. 6に $\mathrm{pH}$ の品質評価のためのプロセスモデル を、Table 2にはそれぞれの品質評価指標に対する 入力值とその基準を示す。これらの基準では、そ の值を定量的に算出することができる項目と、一 般的な知見や経験的な判断から定性的に決定する 項目とに区分できる。例えば、Table 2の項目番号 3 に示した、掘削水による污染が十分に少ないと 判断する基準である $5 \%$ という值は、 $\mathrm{pH}$ の変化が 放射性元素の溶解度に与える影響に基づき決定し た。これまでの研究では、 $\mathrm{pH}$ の值に 0.1 以上の変 化があった場合に放射性元素の溶解度が変化する という結果が得られている (Metcalfe et al., 2004）。この結果に対し、東濃地域での地下水と これまでに使用した掘削水の代表的な值から $\mathrm{pH}$ に0.1以上の変化を与える污染率を $5 \%$ と算出し、 判断の基準とした。ただし、Table 2の項目番号38 に示した採水区間長に関する基準は、調査対象と なるボーリング孔の地質環境に依存するために一 定の值を設定することができない。このような場 合には、各試料について、設定した品質評価指標 を満たしているか否かの判断が必要となる。ま た、本研究においては、各品質評価指標に対する 入力值を $1 、 0$ および0.5として設定している。 不確実性を評価する ESLの特徵を勘案すると、 入力值は今回のような画一的な数值ではなく、各 品質評価指標の内容を定量的に評価し、より具体 
表 1 品質評価に用いたデータの概要と品質評価結果

(Sed：堆積岩, Gr：花崗岩, PS : パッカーサンプラー, 1000PT: $1000 \mathrm{~m}$ 対応水理試験装置, MP: MPシステム, 1000GS：1000m 対応地下水調查機器, HMS : 地下水モニタリ ング装置, PM：ポータブルメーター, DCP : 孔内用地球化学 プローブ)

Table 1 Overview of the data for quality assessment and the result (Sed: Sedimentary rocks, Gr: Granite, PS: Packer Sampler, 1000PT: 1000m Pumping Tester, MP: MPsystem, 1000GS: $1000 \mathrm{~m}$ Groundwater Sampler, HMS: Hydrochemical Monitoring System, PM: Portable Meter, DCP: Downhole Chemical Probe)

\begin{tabular}{|c|c|c|c|c|c|c|c|c|c|}
\hline $\begin{array}{l}\text { サンプル } \\
\text { 番号 }\end{array}$ & 孔名 & \multicolumn{2}{|c|}{$\begin{array}{c}\text { 採取深度 } \\
\text { (masl) }\end{array}$} & 地質 & 採取方法 & の測定方法 & $\mathrm{pH}$ & 真/偽 & 不確実性 \\
\hline$\overline{1}$ & KNA-6 & 136.0 & & Sed.+Gr. & $\overline{\mathrm{PS}}$ & $\overline{\text { HMS }}$ & 9.2 & 71 & $\overline{0.29}$ \\
\hline 2 & KNA-6 & 136.0 & & Sed.+Gr. & PS & HMS & 9.4 & 71 & 0.29 \\
\hline 3 & KNA-6 & 143.0 & & Sed. & PS & HMS & 9.5 & 71 & 0.29 \\
\hline 4 & KNA-6 & 121.0 & & Gr. & PS & HMS & 8.2 & 0.67 & -0.67 \\
\hline 5 & KNA-6 & 121.0 & & Gr. & PS & HMS & 8.5 & 0.66 & -0.66 \\
\hline 6 & MIU-4 & 145.5 & 140.2 & Sed. & $1,000 \mathrm{PT}$ & HMS & 9.4 & 34 & 0.66 \\
\hline 7 & MIU-4 & 134.7 & 100.5 & Gr. & $1,000 \mathrm{PT}$ & HMS & 9.2 & 0.11 & -0.11 \\
\hline 8 & MIU-4 & -55.8 & -57.5 & Gr. & $1,000 \mathrm{PT}$ & HMS & 9.4 & 0.46 & 0.27 \\
\hline 9 & MIU-4 & -288.8 & -343.4 & Gr. & $1,000 \mathrm{PT}$ & HMS & 9.2 & 0.11 & -0.11 \\
\hline 10 & MIU-4 & -436.2 & -422.3 & Gr. & $1,000 \mathrm{PT}$ & HMS & 9.2 & 0.18 & -0.18 \\
\hline 11 & MSB-2 & 119.5 & 115.5 & Gr. & $1,000 \mathrm{PT}$ & HMS & 9.1 & 0.2 & -0.2 \\
\hline 12 & MSB-2 & 66.5 & 44.5 & Sed. & $1,000 \mathrm{PT}$ & HMS & 8.8 & 0.2 & 0.4 \\
\hline 13 & MSB-2 & 27.0 & 23.0 & Gr. & $1,000 \mathrm{PT}$ & HMS & 8.6 & 0.62 & 0.19 \\
\hline 14 & MSB-4 & 198.7 & 188.8 & Sed. & $\overline{\mathrm{MP}}$ & HMS & 7.5 & 0.52 & 0.24 \\
\hline 15 & MSB-4 & 198.7 & 188.8 & Sed. & MP & HMS & 7.3 & 0.52 & 0.24 \\
\hline 16 & MSB-4 & 188.0 & 180.6 & Sed. & MP & HMS & 8.1 & 0.5 & 0.25 \\
\hline 17 & MSB-4 & 179.7 & 152.3 & Sed. & MP & HMS & 7.9 & 0.2 & -0.2 \\
\hline 18 & MSB-4 & 179.7 & 152.3 & Sed. & MP & HMS & 7.9 & 0.2 & -0.2 \\
\hline 19 & MSB-4 & 119.0 & 115.5 & Gr. & $1,000 \mathrm{PT}$ & HMS & 8.8 & 0.54 & 0.23 \\
\hline 20 & MIZ-1 & -8.3 & -19.0 & Gr. & $1,000 \mathrm{PT}$ & HMS & 8.9 & 0.1 & -0.1 \\
\hline 21 & MIZ-1 & -374.1 & -390.4 & Gr. & $1,000 \mathrm{PT}$ & HMS & 8.9 & 0.01 & 0 \\
\hline 22 & MIZ-1 & -442.3 & -519.3 & Gr. & $1,000 \mathrm{PT}$ & HMS & 8.7 & 0.01 & 0 \\
\hline 23 & DH-2 & -13.9 & -15.9 & Gr. & $1,000 \mathrm{PT}$ & HMS & 8.5 & 0.02 & 0.5 \\
\hline 24 & DH-2 & -34.9 & -43.4 & Gr. & $1,000 \mathrm{PT}$ & HMS & 8.7 & 1 & 1 \\
\hline 25 & DH-2 & -109.1 & -111.1 & Gr. & $1,000 \mathrm{PT}$ & HMS & 8.7 & 1 & 1 \\
\hline 26 & DH-2 & -111.9 & -113.9 & Gr. & $1,000 \mathrm{PT}$ & HMS & 8.8 & 1 & 1 \\
\hline 27 & DH-2 & -116.1 & -118.1 & Gr. & $1,000 \mathrm{PT}$ & HMS & 8.8 & 0.02 & 0.5 \\
\hline 28 & DH-2 & -119.4 & -121.4 & Gr. & $1,000 \mathrm{PT}$ & HMS & 8.7 & 1 & 1 \\
\hline 29 & DH-2 & -127.3 & -134.8 & Gr. & $1,000 \mathrm{PT}$ & HMS & 8.6 & 1 & 1 \\
\hline 30 & DH-2 & -154.2 & -156.2 & Gr. & $1,000 \mathrm{PT}$ & HMS & 8.7 & 1 & 1 \\
\hline 31 & DH-2 & -171.9 & -173.9 & Gr. & $1,000 \mathrm{PT}$ & HMS & 8.8 & 1 & 1 \\
\hline 32 & DH-2 & -245.9 & -254.4 & Gr. & 1,000PT & HMS & 8.8 & 1 & 1 \\
\hline 33 & DH-2 & -257.6 & -266.1 & Gr. & $1,000 \mathrm{PT}$ & HMS & 8.7 & 1 & 1 \\
\hline 34 & DH-7 & -97.8 & -104.3 & Gr. & MP & PM & 8.9 & 0.02 & 0.5 \\
\hline 35 & DH-7 & -138.8 & -145.3 & Gr. & MP & PM & 10.3 & 0.02 & 0.5 \\
\hline 36 & DH-7 & -138.8 & -145.3 & Gr. & MP & PM & 9.9 & 0.02 & 0.5 \\
\hline 37 & DH-7 & -220.3 & -226.8 & Gr. & MP & PM & 10.4 & 0.02 & 0.5 \\
\hline 38 & DH-7 & -220.3 & -226.8 & Gr. & MP & PM & 10.1 & 0.02 & 0.5 \\
\hline 39 & DH-7 & -257.8 & -264.3 & Gr. & MP & PM & 10.8 & 0.02 & 0.5 \\
\hline 40 & DH-7 & -257.8 & -264.3 & Gr. & MP & PM & 10.8 & 0.02 & 0.5 \\
\hline 41 & DH-7 & -319.8 & -326.3 & Gr. & MP & PM & 10.1 & 0.02 & 0.5 \\
\hline 42 & DH-7 & -319.8 & -326.3 & Gr. & MP & PM & 9.6 & 0.02 & 0.5 \\
\hline 43 & DH-7 & -395.3 & -401.8 & Gr. & MP & PM & 11.1 & 0.02 & 0.5 \\
\hline 44 & DH-7 & -395.3 & -401.8 & Gr. & MP & PM & 11.2 & 0.02 & 0.5 \\
\hline 45 & DH-7 & -493.3 & -499.8 & Gr. & MP & PM & 10.7 & 0.02 & 0.5 \\
\hline 46 & DH-7 & -539.8 & -546.3 & Gr. & MP & PM & 10.5 & 0.02 & 0.5 \\
\hline 47 & DH-7 & -539.8 & -546.3 & Gr. & MP & PM & 10.7 & 0.02 & 0.5 \\
\hline 48 & DH-12 & -20.1 & -26.7 & Sed. & $1,000 \mathrm{PT}$ & HMS & 9.7 & 0.54 & 0.23 \\
\hline 49 & DH-12 & -34.4 & -142.8 & Gr. & Seepage & HMS & 9.3 & 0.16 & -0.16 \\
\hline 50 & DH-12 & -142.0 & -207.3 & Gr. & Seepage & HMS & 9.2 & 0.09 & -0.09 \\
\hline 51 & DH-12 & -208.5 & -249.8 & Gr. & Seepage & HMS & 8.9 & 0.1 & -0.1 \\
\hline 52 & DH-12 & -251.5 & -292.3 & Gr. & Seepage & HMS & 8.9 & 0.16 & -0.16 \\
\hline 53 & DH-12 & -294.0 & -335.1 & Gr. & Seepage & HMS & 9.2 & 0.09 & -0.09 \\
\hline 54 & DH-15 & 150.2 & 140.7 & Sed. & 1,000PT & HMS & 8.8 & 0.76 & 0.12 \\
\hline 55 & DH-15 & 128.7 & 115.7 & Sed. & $1,000 \mathrm{PT}$ & HMS & 9.1 & 0.48 & 0.26 \\
\hline 56 & DH-15 & 110.5 & 79.5 & Sed. & $1,000 \mathrm{PT}$ & HMS & 10.0 & 0.01 & 0 \\
\hline 57 & DH-15 & 61.1 & -3.2 & Sed. & $1,000 \mathrm{PT}$ & HMS & 9.4 & 0.24 & -0.24 \\
\hline 58 & DH-15 & -20.3 & -26.8 & Gr. & $1,000 \mathrm{PT}$ & HMS & 8.9 & 0.7 & 0.15 \\
\hline 59 & DH-15 & -224.4 & -248.9 & Gr. & 1,000PT & HMS & 8.7 & 0.01 & 0 \\
\hline 60 & DH-15 & -362.3 & -386.8 & Gr. & 1,000PT & HMS & 8.2 & 0.01 & 0 \\
\hline 61 & DH-15 & -551.8 & -568.3 & Gr. & $1,000 \mathrm{PT}$ & HMS & 8.4 & 0.01 & 0 \\
\hline 62 & DH-15 & -723.8 & -740.3 & Gr. & $1,000 \mathrm{PT}$ & HMS & 8.1 & 0.01 & 0 \\
\hline 63 & DH-15 & -773.8 & -790.3 & Gr. & $1,000 \mathrm{PT}$ & HMS & 8.5 & 0.24 & -0.24 \\
\hline
\end{tabular}




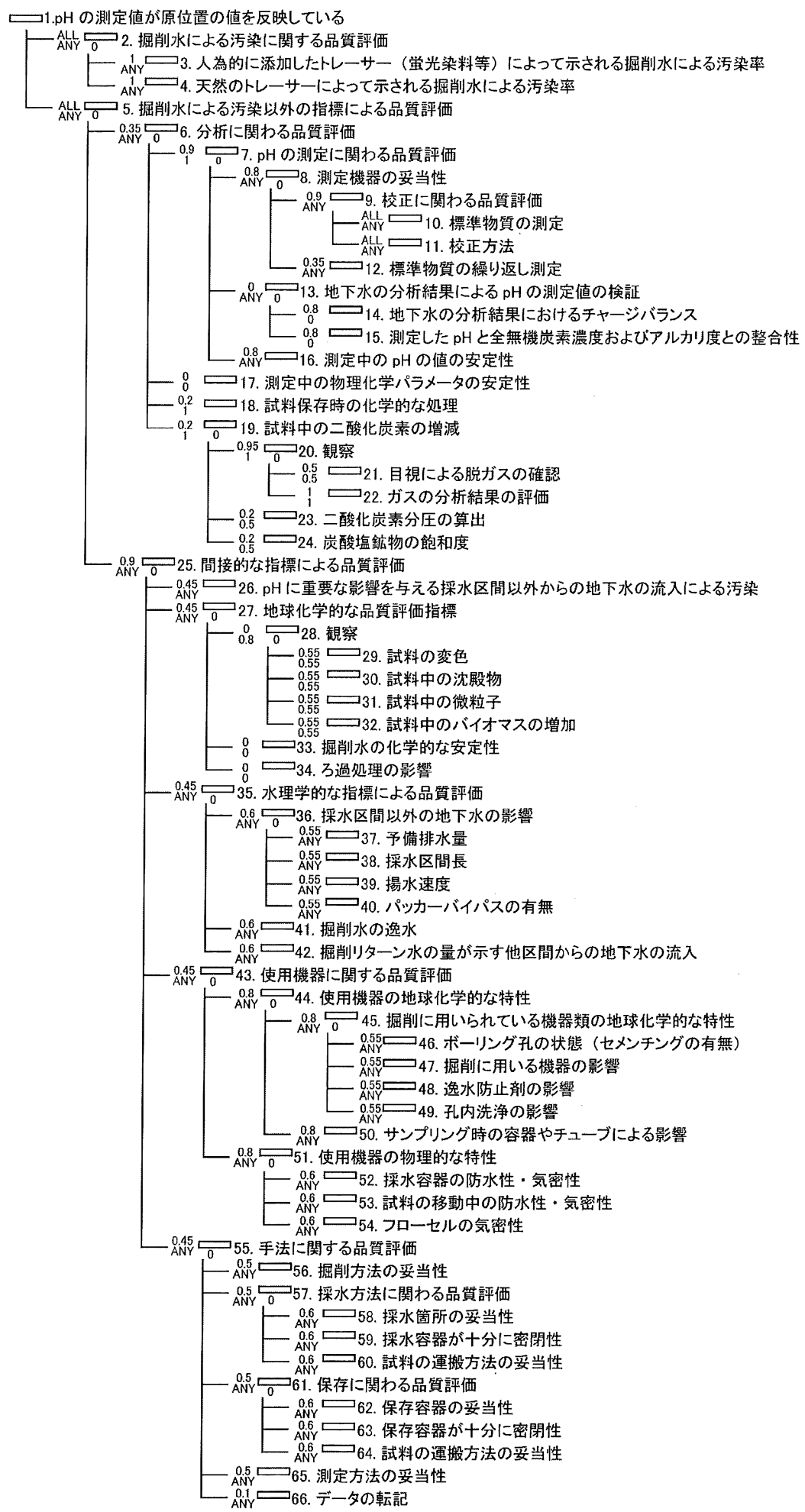

図 6 pH の品質を評価するためのプロセスモデル

Fig. 6 Process model for quality assessment of $\mathrm{pH}$ 
表 $2 \quad \mathrm{pH}$ の品質評価のための品質評価指標と入力値の基準

Table 2 Indicators for quality assessment of $\mathrm{pH}$ and their criteria of input value

\begin{tabular}{|c|c|c|c|}
\hline 項目番号 & 品質評価内容 & 入力值 & 入力値を決定するための基準 \\
\hline \multirow{2}{*}{3} & \multirow{2}{*}{$\begin{array}{l}\text { 人為的に添加したトレーサー(蛍光染料等)によって示 } \\
\text { される掘削水による污染率 }\end{array}$} & 真 $=1$ & 活染率が5\%未満 \\
\hline & & 偽 $=1$ & その他の場合 \\
\hline \multirow[t]{2}{*}{4} & \multirow{2}{*}{$\begin{array}{l}\text { 天然のトレーサー(トリチウムなど)によって示される掘 } \\
\text { 削水による污染率 }\end{array}$} & 真 $=1$ & $\begin{array}{l}\text { 天然のトレーサーが検出できない程度の污染であり, そのトレーサーが掘削水による污染率の適 } \\
\text { 切な指標となることが分かついる昜合 }\end{array}$ \\
\hline & & 偽 $=1$ & 天然のトレーサーが検出できる程度の污染 \\
\hline \multirow{2}{*}{10} & \multirow{2}{*}{ 標準物質の測定 } & 真 $=1$ & 標準物質の測定結果が測定機器で定められた許容範囲内の場合 \\
\hline & & 偽 $=1$ & その他の場合 \\
\hline \multirow{2}{*}{11} & \multirow{2}{*}{ 校正方法 } & 真 $=1$ & 校正方法が測定する地下水に対して適したものである場合 \\
\hline & & 偽 $=1$ & その他の場合 \\
\hline \multirow{2}{*}{12} & \multirow{2}{*}{ 標準物質の繰り返し測定 } & 真 $=1$ & 同じ標準物質に対する繰り返し測定の結果が許容できる範囲に含まれている場合 \\
\hline & & 偽 $=1$ & その他の場合 \\
\hline \multirow{2}{*}{14} & \multirow{2}{*}{ 地下水の分析結果におけるチャージバランス } & 真 $=1$ & チャージバランスが5\%以内の場合 \\
\hline & & 偽 $=1$ & その他の場合 \\
\hline \multirow[t]{2}{*}{15} & \multirow{2}{*}{$\begin{array}{c}\text { 測定したpHと全無機炭素濃度およびアルカリ度との整 } \\
\text { 合性 }\end{array}$} & 真 $=1$ & $\begin{array}{l}\text { アルカリ度とpHについて理論的に算出した結果 (pHと全無機炭酸濃度, アルカリ度を用いて1つの } \\
\text { 項目を他の2つの項目から算出)と実測値の差が3\%以の場合 }\end{array}$ \\
\hline & & 偽 $=1$ & その他の場合 \\
\hline \multirow{2}{*}{16} & \multirow{2}{*}{ 測定中のpHの值の安定性 } & 真 $=1$ & 測定中に測定値が系統的な変化を示さないもしくは変化が測定機器の誤差笘囲内にある場合 \\
\hline & & 偽 $=1$ & その他の場合 \\
\hline \multirow[t]{2}{*}{17} & 測定中の物理化学パラメータの安定性 & 真 $=1$ & $\begin{array}{l}\text { 測定中に他の物理化学パラメータが系統的な変化を示さないもしくは変化が測定機器の誤差範囲 } \\
\text { 内にある場合 }\end{array}$ \\
\hline & me & 偽 $=1$ & その他の場合 \\
\hline 18 & 試料保存時の化学的な処理 & 真 $=1$ & $\begin{array}{l}\text { 実験室で測定され化学的な保存処理がpHに影響を与えていない場合 } \\
\text { フローセルで測定され化学的な保存処理が行われていない場合 }\end{array}$ \\
\hline & & 偽=1 & 保存剂が添加されてpHに影響を与えている場合 \\
\hline 21 & & 真 $=1$ & 目視で脱ガスが認められない場合 \\
\hline 21 & 日視にーよる脱刀人U碓誌 & 偽 $=1$ & 脱ガスが認められる場合 \\
\hline 22 & ガスの分析結里の評価 & 真 $=1$ & 脱ガスしたガスの分析が行われて $\mathrm{CO}_{2}$ が含まれている場合 \\
\hline & 刀人の分析喆未の評佃 & 偽 $=1$ & CO2が含まれている場合 \\
\hline 23 & 一酸化岸量分厂の筑出 & 真 $=1$ & 大気の值と大きく違う場合 \\
\hline 20 & 一毁化灰系分俚U暑出 & 偽 $=1$ & 大気の值と同じ場合 \\
\hline 24 & 崖酸晧鉱物の飽和度 & 真 $=1$ & 炭酸塩鉱物の飽和度が $\pm 0.2 の$ 範囲内にある場合 \\
\hline & 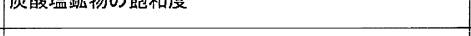 & 偽 $=1$ & その他の場合 \\
\hline & & 真 $=1$ & 他の区間からの地下水の流入がpHに影響を与えていない(pHが0.1以上变化していない)場合 \\
\hline 26 & 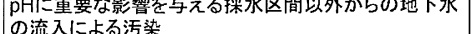 & 偽 $=0.5$ & 他の区間からの地下水の流入がpHに影響を与えている可能性がある場合 \\
\hline & & 偽 $=1$ & 他の区間からの地下水の流入がpHに影響を与えている場合 \\
\hline 29 & & 真 $=1$ & 試料が変色していない場合 \\
\hline 29 & 試料の盗也 & 偽 $=1$ & その他の場合 \\
\hline 30 & 試料中の浓殿物 & 真 $=1$ & 沈殿物が存在していない場合 \\
\hline 30 & 試料中の沉版物 & 偽 $=1$ & その他の場合 \\
\hline 31 & 試料中の微粒子 & 真 $=1$ & 微粒子が存在しない場合 \\
\hline 31 & 試科中心橵槛于 & 偽 $=1$ & その他の場合 \\
\hline 32 & 試料中のバイオマスの増加 & 真 $=1$ & パイオマスが存在しない場合 \\
\hline & 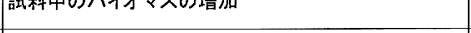 & 偽 $=1$ & その他の場合 \\
\hline & & 真 $=1$ & 掘削水の化学組成が安定しており掘削水による污染の結果が単純な2成分の混合である場合 \\
\hline 33 & 掘削水の化学的な安定性 & 偽 $=0.5$ & 掘削水の化学組成が安定していない可能性がある場合 \\
\hline & & 偽 $=1$ & 掘削水の化学組成が安定でない場合 \\
\hline & & 真 $=1$ & $\begin{array}{l}\text { 地下水試料のろ過がpHIに0.1以上の変化を与えない場合 } \\
\text { pHをフローセルどで測定することによってろ過が不要となる場合 }\end{array}$ \\
\hline 34 & ろ過処理の影響 & 偽 $=0.5$ & ろ過によってpHが0.1以上の変化を受けいている可能性がある場合 \\
\hline & & 偽 $=1$ & ろ過によってpHが0.1以上の変化を受けいている場合 \\
\hline & & 真 $=1$ & 予備排水量が採水区間以外から地下水の流入をおこさない量の場合 \\
\hline 37 & 予備排水量 & 偽 $=0.5$ & 予備排水量が他の区間からの地下水流入を引き起こす可能性がある量の場合 \\
\hline & & 偽 $=1$ & 他の区間からの地下水の流入を引き起こしていると考えられる場合 \\
\hline & & 真 $=1$ & 採水区間長が短く化学的特性の異なる地下水の流入を引き起こすことがない場合 \\
\hline 38 & 採水区間長 & 偽 $=0.5$ & 採水区間長が長く化学的特性の異なる地下水の流入を引き起こす可能性がある場合 \\
\hline & & 偽 $=1$ & 採水区間長が長く化学的特性の異なる地下水の流入を引き起こす場合 \\
\hline & & 真 $=1$ & 揚水速度が適切であり化学的特性の異なる地下水による混合が起きない場合 \\
\hline 39 & 揚水速度 & 偽 $=0.5$ & 揚水速度が速く化学的特性の異なる地下水が混入する可能性がある場合 \\
\hline & & 偽 $=1$ & 揚水速度が速く化学的特性の異なる地下水が混入する場合 \\
\hline 40 & パッカーバイパスの有無 & 真 $=1$ & 区間圧カの反応からパッカーバイパスがない場合 \\
\hline 40 & ハッカーハイハ人日有無 & 偽 $=1$ & その他の場合 \\
\hline & & 真 $=1$ & 掘削中の逸水量が少なく原位置の地下水への混入が起こらない場合 \\
\hline 41 & 掘削水の逸水 & 偽 $=0.5$ & 逸水量が大きく原位置の地下水の化学特性に影響を与える可能性がある場合 \\
\hline & & 偽=1 & 逸水量が大きく原位置の地下水の化学特性に影響を与える場合 \\
\hline
\end{tabular}


表 2 続き

Table 2 Continued

\begin{tabular}{|c|c|c|c|}
\hline 項目番号 & 品質評価内容 & 入力值 & 入力値を決定するための基準 \\
\hline \multirow{3}{*}{42} & \multirow{3}{*}{ 掘削リターン水の量が示す他区間からの地下水の流入 } & 真=1 & $\begin{array}{l}\text { 掘削リターン水の量によってボーリング孔内に流入した地下水が異なる深度の地下水に化学的な } \\
\text { 彎を与えていない場合 }\end{array}$ \\
\hline & & 偽 $=0.5$ & 5 掘削リターン水の量によってボーリングれ内に流入した地下水が翼なる深度の地下水に化学的な \\
\hline & & 偽=1 & $\begin{array}{l}\text { 掘削リターン水の量によってボーリング孔内に流入した地下水が異なる深度の地下水に化学的な } \\
\text { 的なとえている場合 }\end{array}$ \\
\hline \multirow{3}{*}{46} & \multirow{3}{*}{ ボーリング孔の状態(セメンチングの有無) } & 真 $=1$ & セメントがpHI影響を与えていないもしくはセメントを使用していない場合 \\
\hline & & 偽 $=0.5$ & 5 セxントがрHに影響を与えている可能性がある場合 \\
\hline & & 偽 $=1$ & セメントがpHに影響を与えている場合 \\
\hline \multirow{3}{*}{47} & \multirow{3}{*}{ 掘削に用いる機器の影響 } & 真 $=1$ & 掘削に用いる機器と地下水の反応による影響がpHにない場合 \\
\hline & & 偽 $=0.5$ & 5 掘削に用いる機器と地下水の反応によりpHが変化する可能性がある場合 \\
\hline & & 粡=1 & 掘削に用いる機器と地下水の反応によりpHが変化している場合 \\
\hline \multirow{3}{*}{48} & \multirow{3}{*}{ 逸水防止㓮の影響 } & 真 $=1$ & 逸水防止剂を使用していないもしくは使用してもpHに影響を与えない場合 \\
\hline & & 偽 $=0.5$ & 5 逸水防止戍が地下水と反応してpHに影響を与える可能性がある場合 \\
\hline & & 偽=1 & 逸水防止剂が地下水と反応してpHに影響を与える場合 \\
\hline \multirow{3}{*}{49} & \multirow{3}{*}{ 孔内洗浄の影響 } & 真 $=1$ & 孔内洗浄が行われていないもしくは孔内洗浄によりрHが影響を受けていない場合 \\
\hline & & 偽 $=0.5$ & 5 孔内洗浄によりpHが变化する可能性がある場合 \\
\hline & & 偽=1 & 孔内泩浄によりDHが変化する場合 \\
\hline \multirow{2}{*}{50} & \multirow{2}{*}{ サンプリング時の容器やチューブによる影響 } & 真 $=1$ & 採水時の容器やチューブが地下水と反応しない場合 \\
\hline & & 偽=1 & その他の場合 \\
\hline \multirow{2}{*}{52} & \multirow{2}{*}{ 採水容器の防水性·気密性 } & 真 $=1$ & 採水容器が防水および気密を保てるものである場合 \\
\hline & & 偽=1 & その他の場合 \\
\hline \multirow{2}{*}{53} & \multirow{2}{*}{ 試料の移動中の防水性·気密性 } & 真 $=1$ & 試料の移動中にも防水·気密を保てる場合 \\
\hline & & 偽=1 & その他の場合 \\
\hline \multirow{2}{*}{54} & \multirow{2}{*}{ フローセルの気密性 } & 真 $=1$ & フローセルの気密が保たれている場合もしくはフローセルを使用していない場合 \\
\hline & & 偽=1 & フローセルの気密が保たれていない場合 \\
\hline \multirow{3}{*}{56} & \multirow{3}{*}{ 掘削方法の妥当性 } & 真 $=1$ & $\begin{array}{l}\text { 掘削方法が適切であり原位置の地下水に化学的な変化を起こさないまたは地下水の分布を空間 } \\
\text { 的に乱さない場合 }\end{array}$ \\
\hline & & 偽 $=0.5$ & $\begin{array}{l}\text { 掘削方法が適切でなく原位置の地下水に化学的な変化を起こしているまたは地下水の分布を空間 } \\
\text { 的にている可能性が場合 }\end{array}$ \\
\hline & & 伪=1 & $\begin{array}{l}\text { 掘削方法が適切てなく原位置の地下水に化学的な変化を起こしているまたは地下水の分布を空間 } \\
\text { 的に乱ている場合 }\end{array}$ \\
\hline \multirow{3}{*}{58} & \multirow{3}{*}{ 採水箇所の妥当性 } & 真=1 & $\begin{array}{l}\text { 孔内で採水した場合，pHを孔内で測定した場合，地表でpHを測定して値が長い時間で安定だった } \\
\text { 場合 }\end{array}$ \\
\hline & & 偽 $=0.5$ & $\begin{array}{l}\text { pHの測定は地表で行っているがpHの変化を防ぐような方法で測定を行った場合およびフローセル } \\
\text { で測定を行っているが測定の長期的な安定性を確認していない場合 }\end{array}$ \\
\hline & & 偽=1 & 採水箇所でどのような影響がpHIこあるか不明な場合 \\
\hline \multirow{2}{*}{59} & 採水容器が十分に密閉性 & 真 $=1$ & 採水容器が十分に密閉されており空気が入ったり試料が蒸発することがない場合 \\
\hline & & 偽=1 & その他の場合 \\
\hline 60 & 試料の運搬方法の妥当性 & 真 $=1$ & 試料の運搬中に漏洩等がない場合 \\
\hline & & 偽=1 & その他の場合 \\
\hline & & 真 $=1$ & 容器の状態が試料に化学的な影響を与えないものである場合 \\
\hline 62 & 保存容器の妥当性 & 偽 $=0.5$ & 容器の状態が試料に化学的な影響を与える可能性がある場合 \\
\hline & & 偽 $=1$ & 容器の状態が試料に化学的な影響を与える場合 \\
\hline & & 真 $=1$ & 保存容器が十分に密閉されており殿洩がない場合 \\
\hline 63 & 保存容器が十分に密閉性 & 偽 $=0.5$ & 漏油する可能性がある保存容器の場合 \\
\hline & & 偽 $=1$ & 漏沂する保存容器の場合 \\
\hline & & 真 $=1$ & 試料の運搬中に漏洩がない場合 \\
\hline 64 & 試料の運搬方法の妥当性 & 偽 $=0.5$ & 試料の運搬中に漏洩の可能性がある場合 \\
\hline & & 㑋=1 & 試料の運搬中に漏洩する場合 \\
\hline & & 真 $=1$ & 測定方法および使用機器が適切である場合 \\
\hline 65 & 測定方法の妥当性 & 偽 $=0.5$ & 測定方法および使用機器が適切でない可能性がある場合 \\
\hline & & 偽=1 & 測定方法および使用機器が適切でない場合 \\
\hline 66 & データの転記 & 真 $=1$ & データの転記についてチェックが行われている場合 \\
\hline 00 & 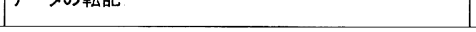 & 偽=1 & その他の場合 \\
\hline
\end{tabular}

的に決定することが望ましい。ただし、各品質評 価指標への入力值を定量的に評価するためには、 現場での確認作業や分析項目が増加し、調査期間 やコストが増大する可能性がある。また、過去に 取得したデータについて品質評価を行う場合に
は、品質評価に関する情報を取得するのは困難で ある。そのため、本研究では各品質評価指標にお いて従来の調査手法で得られた情報に基づき、確 実に品質評価指標を満たすもしくは満たさないと する基準を設定し、入力值を決定した。また、該 

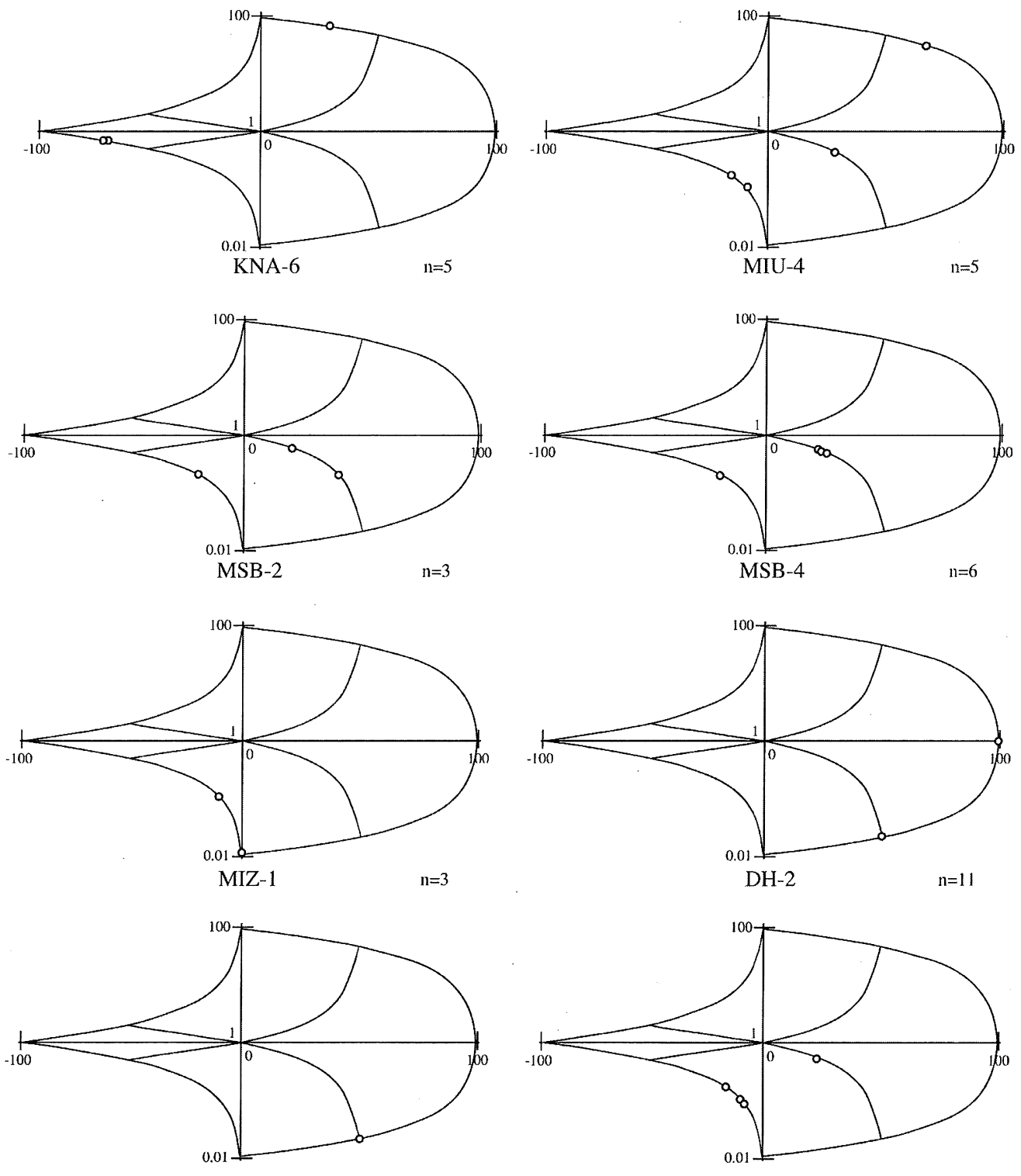

DH-2

$\mathrm{n}=11$

DH-7

$n=14$

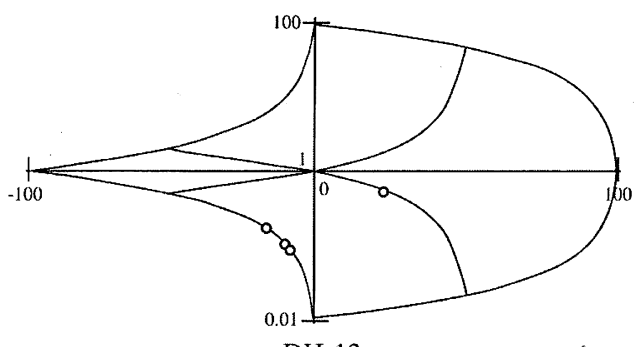

DH-12

$n=6$
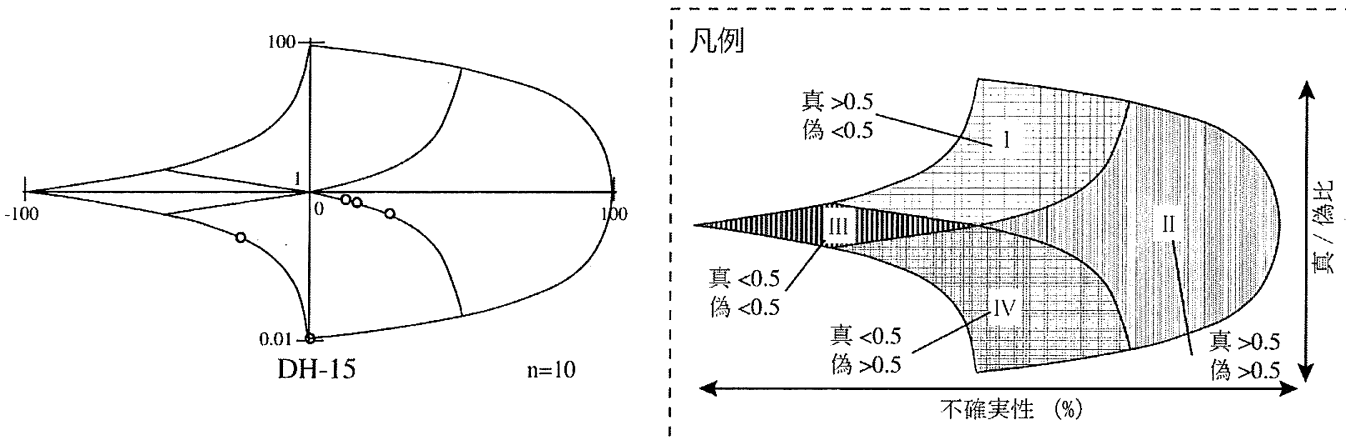

図 7 pHの品質評価結果を示した相関プロット

Fig. 7 Correlation plots showing the result of quality assessment of $\mathrm{pH}$ 
当する品質評価指標に関する情報が欠損している 場合には、不確実性を1として設定した。

各試料の概要および品質評価結果を Table 1に示 す。また、品質評価結果の相関プロットを Fig. 7 に示す。この相関プロットは、真/偽比を $\mathrm{Y}$ 軸に、 不確実性を X 軸にしている。Y 軸は対数表示であ る。本稿ではこの相関プロットを真偽の割合に基 ついて区分し、便宜的に、品質の高い順から I、 II 、III、IVとした（Fig. 7)。ボーリング孔ごとに 結果をみてみると、 $\mathrm{DH}-7$ 号孔における $\mathrm{pH}$ の測定 值は、全てのデータで同じ值を示し、品質が低い 結果となった。 $\mathrm{DH}-7$ 号孔では蛍光染料の添加な どによる掘削水の管理が正確に行われておらず、 掘削水による污染の程度が把握できないことがこ の品質が低い原因となった。また、DH-2号孔の 結果についても DH-7号孔と同様に掘削水の管理 が十分でなかったため、不確実性が100\%となる 結果となった。その他、MIU-4、DH-12、DH15、MIZ-1、MSB-2号孔およびMSB-4号孔のそ れぞれにおいて、掘削水による污染や掘削水の管 理方法については十分な品質を示したものの、 $\mathrm{pH}$ データの品質についてはばらついた結果を示 した。これらのボーリング孔から取得されたデー 夕において、低い品質を示す結果となったデータ に共通する項目として、採水の区間長が長いこと および採水の前に行う予備排水の量が適切でない ことが挙げられる。採水区間の区間長が地下水の 品質に与える影響についてはSKB が検討した事 例があり（Laaksoharju、2004）、区間長が長い場 合には区間以外からの地下水の流入が起きる可能 性が高いという結果を示している。また、予備排 水の量については、少なすぎる場合には掘削水が 十分に排除できないが、多すぎる場合には他の区 間から地下水を流入させることとなり、新たな污 染が生じる可能性がある。これらの点について は、採水区間の区間長をより短く設定すること や、トレーサーによる掘削水の污染率を把握した 上での予備排水量の管理などにより、適切な方法 によって採水を行う必要がある。また、これら以 外の品質を低下させている要因として、 $\mathrm{pH}$ の值 が溶存無機炭素、アルカリ度と整合的でないこと や、 pH の測定中に值が安定していないこと、脱 ガスが認められることなどがある。これらについ
ては、物理化学パラメー夕を被圧、不活性状態で 測定することや、採水現場で測定するだけでな く、分析を行う実験室でも再度測定し、分析結果 との整合性を確認するなどの改善をすることで、 より品質の高いデー夕を得られる可能性がある。

品質評価結果に基づいた $\mathrm{pH}$ の深度分布を Fig. 8 に示す。Fig. 8(a) には全てのデータがプロット してあり、Fig. 8(b) には相関プロットにおいて I およびIに分類されたデータのみをプロットし た。IIとIVの境界にプロットされたデータについ ては、それぞれIIのデータとして取り扱った。た だし DH-2およびDH-7のデータについては除外 した。Fig. 8のどちらの場合においても、標高約 $100 \mathrm{~m}$ までは、 $\mathrm{pH}$ が7から10の間で深度とともに 増加する傾向が認められる。ただし、標高約 100m 以深において、Fig. 8(a) のプロットでは $\mathrm{pH}$ が 8 から12の範囲に分布し、深度との相関は 認められなかった。これに対し、Fig. 8(b) では、 $\mathrm{pH}$ は概ね 8 から 9 のより狭い範囲に分布し、各 深度でほぼ一定の值を示した。この結果から、地 下水データの品質を評価し、一定の基準以上の データを用いることによって、より正確に地下深 部までの環境を把握できるようになると考えられ る。

また、 $\mathrm{pH}$ 以外の項目、酸化還元電位や塩化物 イオン濃度などについても、品質評価指標の変更 や各パラメータを適切に設定することで、 $\mathrm{pH}$ と 同様にその品質を評価できると考えられる。ただ し、本稿で例示した品質評価指標やそれらの基 準、各パラメータなどは、東濃地域で用いている 調查方法や東濃地域の地質掞よび水質を前提とし て決められている。そのため、他の方法、他の地 域で同様に品質評価を行う場合には、プロセスモ デルを研究地域の条件を考慮した上で再構築し、 品質評価を行う必要がある。

\section{4. まとめ}

本研究の品質評価手法に基づき調査を評価し、 結果を研究に反映させることで、より正確に地下 深部における地球化学環境を把握できることが示 された。本手法においては、品質評価のための係 数の選択や、それぞれの係数の重み付けなどに検 

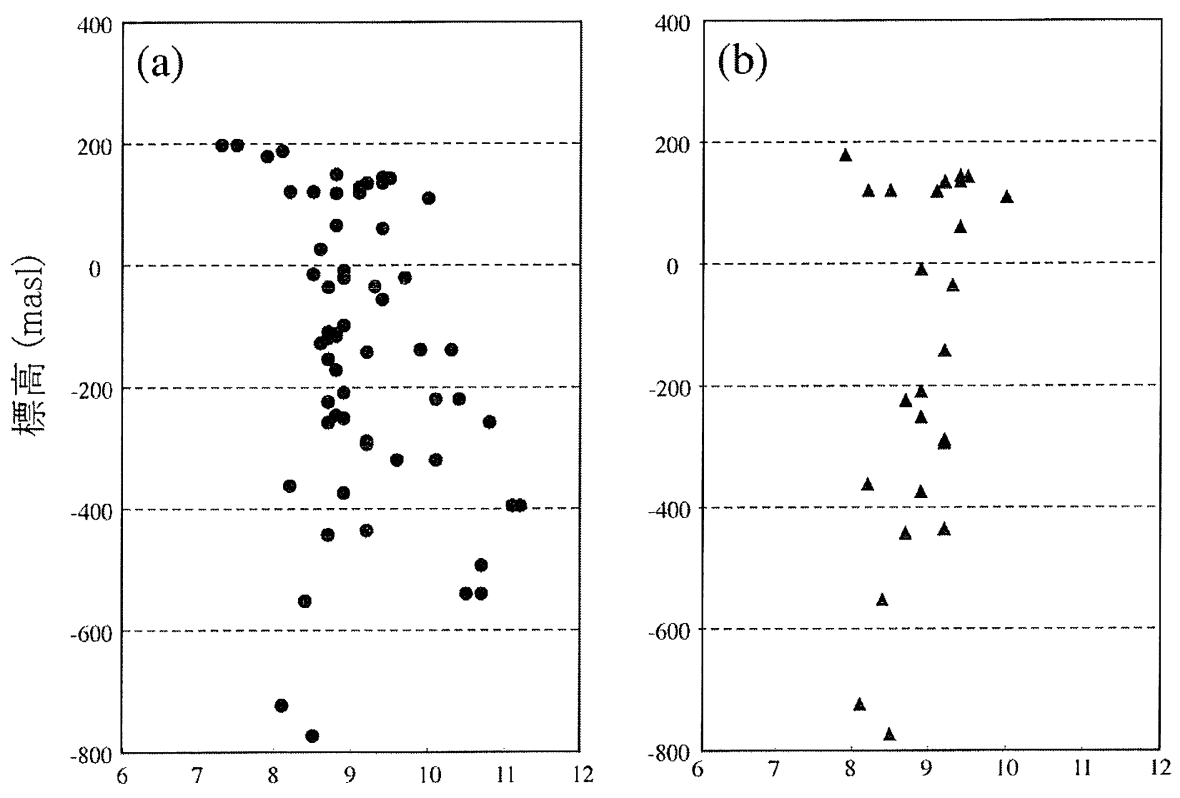

$\mathrm{pH}$

图 $8 \mathrm{pH}$ の深度分布（(a) 全データ、(b) 一定以上の品質のデータ）（masl = meters above sea level)

Fig. 8 Depth profile of $\mathrm{pH}$ ((a) all data, (b) classified high-quality data) (masl = meters above sea level)

討課題は残るものの、品質評価手法としては有効 であると考えられる。

\section{謝辞}

本報告を作成するにあたり、貴重なご意見を賜 りました匿名の査読者に感謝致します。

\section{参考文献}

岩月輝希・豊嶋賢治·吉田英一（1998）：深地層を対象 とした地下水の地球化学調査の現状．原子力バック エンド研究、4、73 81

小宮洋行 · 中屋眞司 ·益田晴恵・日下部実 (2003)：酸 素抒よび水素の安定同位体比と水質から見た長野県 松本盆地中 - 南部地域の広域地下水流動系. 日本地 下水学会誌、45、145 168

日本地下水学会 (2000)：『地下水水質の基礎－名水から 地下水污染まで』理工図書
古江良治、岩月輝希、濱 克宏 (2005) : 深層ボーリン グ孔を用いた地下水の地球化学調查の課題に対する 試み、応用地質、46、232 236

Blockley D.I., and Godfrey P. (2000): Doing it differently - system for rethinking construction, Thomas Telford, London

Cui W. and Blockley D.I. (1990): Interval probably theory for evidential support, Inter. Jour. Intelli. Sys., 5, 183 192

Davis J.P. and Hall J.W. (2003): A software-supported process for assembling evidence and handling uncertainty in decision-making, Decision Support System, 35, 415 433

Foley L., Ball L., Hurst A., Davis J. and Blockley D. (1997): Fuzziness, incompleteness and randomness: Classification of uncertainty in reservoir appraisal, Petroleum Geoscience, 3, 203 209

Furue R., Iwatsuki T., Mizuno T., Mie H. (2003); Data book on groundwater chemistry in the Tono area, 
JNC TN7450 2003-001

Gascoyne, M. (2004): Hydrogeochemistry, groundwater age and sources of salts in a granitic batholith on the Canadian Shield, Southeasten Manitoba. Appl. Geochem. 19, 519 560

Hall J.W., Blockley D.I., and Davis J.P. (1998): Uncertain inference using interval probability theory, Inter. Jour. Approx. Appli. Reason., 19, 247 264

Laaksoharju M., Smellie J., Ruotsalainen P., Snellman M. (1993): An approach to quality classification of deep groundwaters in Sweden and Finland, $S K B$ Tech. Rep., 93 27

Laaksoharju M., (2004); Hydrogeochemical evaluation for Simpevarp model version 1.2. Preliminary site description of the Simpevarp area, SKB Report R04-74

Metcalfe R., Savage D., Bath A.H. and Walker C., (2004): 核種の溶解度評洒に関する地下水の地球化 学パラメータの感度解析、JNC TJ7400 2004-013

(受付：2006年 7 月 26 日、受理：2007年 3 月 30 日) 